\title{
Factors Associated with the Onset of Ovarian Activity of Cattle Commonly Reared in the Huasteca Veracruzana, Mexico
}

\author{
Olivares-Sixto, Luciano ${ }^{1}$; Silva-Martínez, Karla L. ${ }^{1}$; Vite-Cristóbal, Claudio ${ }^{1}$; Del Ángel-Piña, Oscar ${ }^{1}$; \\ Arrieta-González, Armando ${ }^{1^{*}}$ \\ ${ }^{1}$ Tecnológico Nacional de México/Instituto Tecnológico Superior de Tantoyuca. Tantoyuca, Veracruz, \\ México. C. P. 92100 \\ *Corresponding author: armando.arrieta@itsta.edu.mx
}

\begin{abstract}
Objective: To identify the factors that affect the onset of ovarian activity in prepuberal heifers in the Huasteca Veracruzana of Mexico.

Design/Methodology/Approach: Samples were taken from animal production units of the municipality of Tantoyuca, Veracruz. The onset of ovarian activity was determined by the presence of ovarian follicles and corpus luteum by ultrasonography technique. Zoometric indices and body condition were calculated at the same time, and the zootechnical practices that were applied to the animals in the last six months before the sampling day were registered. A survey was applied to characterize the management of animal production units; the main topics in the survey were: health, reproduction, nutrition, and suckling. All animals available within selection criteria in the production units were sampled. A multiple linear regression (Statistical Analysis Software Version 9.4) and cluster analysis (R Studio Version 1.1.419) were used to identify the main categorical variables that affected the model.

Results: The onset of ovarian activity depends mainly on the anatomical development of the heifers. The biostimulation (male effect) on the heifers has an important effect on reducing the age at puberty.

Study Limitations/Implications: The study was developed during a long drought period in the region.

Findings/Conclusions: The genetic mosaic of the evaluated animals in the production units did not affect the onset of ovarian activity of the heifers; however crossbred heifers (Bos taurus $\times$ Bos indicus) begin the ovarian activity younger.
\end{abstract}

Keywords: Male effect, reproductive efficiency, zoometrics.

Citation: Olivares-Sixto, Luciano, SilvaMartínez, Karla L., Vite-Cristobal, Claudio, Del Ángel-Piña, Oscar, Arrieta-González, Armando. (2021). Factors associated with the onset of ovarian activity of cattle commonly reared in the Huasteca Veracruzana. Agro Productividad, 14(\#). https://doi. org/10.32854/agrop.v14i6.1852

Editor in Chief: Dr. Jorge Cadena Iñiguez

Estimated publication date: July 2021

This work is licensed under a Creative Commons Attribution-NonCommercial 4.0 International license (c) $\$$

\section{INTRODUCTION}

The dual purpose cattle production system (DPCPS) is developed in most of the tropical regions of Latin America, and in this system extensive grazing is the most widely used (Vilaboa and Díaz, 2009). Meat and milk production depends on this system in this region (Orantes et al., 2010). The DPCPS in Veracruz contributes to the national total of around 739 thousand tons of standing livestock and carcass and 745.30 million liters of milk annually. Therefore, livestock production is one of the activities that contributes most to the economy in Veracruz; 53.70\% of the surface of this state is devoted to livestock production (PSAV, 2019). The DPCPS is characterized by having low productive and reproductive indices compared to the specialized animal production systems (beef and dairy cattle). One of these indices is the age at puberty, which can be defined as the moment when females physiologically start the capacity to reproduce (Estill, 2014). The onset of puberty is determined by age, and this process also depends on an undefined order of physiological conditions that result from a specific critical weight (Kenny et al., 2018), for others, body development and nutrition are more important (Grajales et al., 2006). The beginning of ovarian activity is a parameter that 
affects the fertility of the herd and this in turn affects the productive level of a livestock system (Osorio-Arce and Segura-Correa, 2002; Teyer et al., 2003; Parra-Bracamonte et al., 2005). Given the importance of this physiological event, this study identifies some factors that affect the beginning of the ovarian activity in heifers bred in DPCPS in the Huasteca Veracruzana (HV).

\section{MATERIALS AND METHODS}

The research work was carried out in the municipality of Tantoyuca, Veracruz, located in the mountainous zone of the HV, in coordinates $98^{\circ} 14^{\prime}$ Longitude West and $21^{\circ} 21^{\prime}$ Latitude North, at an average altitude of 140 meters above sea level. Its climate is warm-extreme with an annual average temperature of $23^{\circ} \mathrm{C}$; the mean annual rainfall fluctuates between 1,000 and 1,500 mm (INEGI, 2010).

The study was performed in the last six months of the year 2019, and 73 prepuberal heifers (12-24 months of age) were included, from nine livestock production units devoted to DPCPS in the municipality of Tantoyuca, Ver. The genetic groups of the animals sampled were: I. Bos indicus, II. Bos taurus, III. B. indicus $\times$ B. Taurus Cross, IV. Predominance of $B$. indicus, and V. Predominance of $B$. taurus. The dependent variables evaluated were: right ovary follicular activity (ROFA), left ovary follicular activity (LOFA), right ovary size (ROS), left ovary size (LOS), right ovary shape (ROSh) and shape of the left ovary (LOSh). The ROFA and LOFA were determined with the presence of follicles and corpus luteum. Three categories were established for ROS and LOS: I. (<1 $\mathrm{cm})$, II. $(1-2 \mathrm{~cm})$, and III. ( $>2 \mathrm{~cm})$. These variables were measured with ultrasound techniques (Mindray DP 10-VET). The ROSh and LOSh were determined through the rectal palpation technique, establishing three categories: I. Amorphous, II. Oval plane, and III. Oval cylindrical. In addition, the following values were found: body condition (Edmonson et al., 1989), biometric measurements of the heifer's trunk (Fernandes et al., 2010; Dubuc, 1991; Contreras et al., 2011), proximity to the male (males and females together or separate), number of technological-productive practices implemented in herd management (nutrition-health index), and zoometric indices of anatomical development (Contreras et al., 2011).

\section{Data analysis}

The systematization of information was digitalized in the Microsoft Excel 2016 software. The data were processed through a multiple linear regression analysis with the statistical package SAS version 9.4 and the REG procedure, in order to explain the possible relationships between independent and dependent variables. The independent or categorical variables were: ranch $\left(\mathrm{X}_{1}\right)$, race $\left(\mathrm{X}_{2}\right)$, age $\left(\mathrm{X}_{3}\right)$, body condition $\left(\mathrm{X}_{4}\right)$, proximity of male $\left(\mathrm{X}_{5}\right)$, nutrition-health index $\left(\mathrm{X}_{6}\right)$, thoracic index $\left(\mathrm{X}_{7}\right)$, body index $\left(\mathrm{X}_{8}\right)$, lateral body index $\left(\mathrm{X}_{9}\right)$, and transverse-pelvic index $\left(\mathrm{X}_{10}\right)$. Meanwhile, the dependent variables corresponded to: ROSh, ROS, ROFA, LOSh, LOS, and LOFA. A cluster analysis was carried out, which allowed identifying the management differences between the livestock production systems studied, and which in turn 
impacted the beginning of the ovarian activity; this was done through the statistical package R Studio Version 1.1.419.

\section{RESULTS AND DISCUSSION}

The regression equations that showed significant impact $(p<0.0001)$, of the categorical variables (ranch, race, age, bodily condition, proximity to the male, nutrition-health index, thoracic index, bodily index, lateral body index, transversepelvic index) on the response variables were: LOS, LOFA, ROFA and ROS. Multiple determination coefficients were obtained with these equations, with values higher than $42 \%$. The equations related to the response variables LOFA and ROFA showed a value of $\mathrm{R}^{2}$ of $47 \%$, which indicates a moderate adjustment of the data of the model designed for these equations only under LOS, which for these same models was significant $(\mathrm{p}<0.0001)$. This result could be consequence of the genetic mosaic found in the bovines studied and the variability in the nutritional and sanitary management that is given to the animals in the different livestock production units where the study was performed; in this regard, Heslin et al. (2020) found that heifers who had daily weight gains of $1 \mathrm{~kg}$ during 150 days began puberty at a younger age, and this is because a better diet allows a greater anatomical development and favors the physiological maturation as a result of higher contribution of energy and protein in the diet.

The model for the variable LOSh obtained an $R^{2}$ of $17 \%(p=0.24)$, and these results are the ones of lowest value of all the equations developed. The data related to this equation are not adjusted to the model and therefore lack practical importance in the conditions under which this study was carried out. For the case of ROSh, the model was significant with an $\mathrm{R}^{2}$ of $30 \%(\mathrm{p}=0.0081)$. This indicates that data adjustment regarding the model is not conclusive (Table 1 ).

The modelled variables ROFA and LOFA were affected primarily by the categorical variables, body index (BI) $(p=0.0002)$, lateral body index (LBI) $(p=0.0009)$, thoracic index (TI) $(p=0.001)$ and age (A) $(p=0.01)$. These two models were affected moderately by the categorical variable PM $(p=0.13)$. The rest of the categorical variables showed a non-significant impact toward the models.

The onsert of the ovarian activity of the heifers raised in the dual-purpose system in the Huasteca Veracruzana is influenced by the anatomical development and chronological age, and concerning this Cardoso et al. (2021) mention that body weight and physical development are the main factors that determine the age at puberty, and they also indicate that they are closely related with the weight at birth, which can be compromised by nutritional deficiencies of the mother during gestation. Maternal nutrition is directly related to the functioning of the neuroendocrine system so that it can modulate the hypothalamus routes that control the secretion of the gonadotropin liberating factor. 
Table 1. Multiple regression equations of ROFA, LOFA, ROS, LOS, ROSh and LOSh, $\mathrm{R}^{2}$ and significance level.

\begin{tabular}{l|l|c|c}
\hline Variable & \multicolumn{1}{|c|}{ Equation } & \multicolumn{1}{|c}{$\mathbf{R}^{2}$} & Significance \\
\hline ROSh & $\begin{array}{l}y=5.43-0.004 x_{1}-0.19 x_{2}+0.05 x_{3}-0.11 x_{4}+0.93 x_{5}+3.39 x_{6}-0.007 x \\
7-0.03 x_{8}-0.02 x_{9}-0.07 x_{10}\end{array}$ & 0.30 & 0.0081 \\
\hline ROS & $\begin{array}{l}y=16.84+0.11 x_{1}-0.009 x_{2}+0.03 x_{3}+0.33 x_{4}+0.24 x_{5}-1.91 x_{6}-0.05 x \\
7-0.08 x_{8}-0.03 x_{9}+0.02 x_{10}\end{array}$ & 0.42 & 0.0001 \\
\hline ROFA & $\begin{array}{l}y=28.68+0.003 x_{1}-0.001 x_{2}+0.02 x_{3}+0.01 x_{4}-0.16 x_{5}-0.46 x_{6}-0.06 \\
x_{7}-0.13 x_{8}-0.07 x_{9}-0.009 x_{10}\end{array}$ & 0.47 & 0.0001 \\
\hline LOSh & $\begin{array}{l}y=16.72+0.001 x_{1}-0.11 x_{2}+0.004 x_{3}-0.25 x_{4}+0.76 x_{5}+1.95 x_{6}-0.04 \\
x_{7}-0.07 x_{8}-0.04 x_{9}-0.02 x_{10}\end{array}$ & 0.17 & 0.2412 \\
\hline LOS & $\begin{array}{l}y=40.12+0.13 x_{1}-0.07 x_{2}+0.02 x_{3}+0.28 x_{4}+0.47 x_{5}-2.08 x_{6}-0.11 x_{7} \\
-0.17 x_{8}-0.09 x_{9}-0.02 x_{10}\end{array}$ & 0.52 & 0.0001 \\
\hline LOFA & $\begin{array}{l}y=28.68+0.003 x_{1}-0.001 x_{2}+0.02 x_{3}+0.01 x_{4}-0.16 x_{5}-0.46 x_{6}-0.06 \\
x_{7}-0.13 x_{8}-0.07 x_{9}-0.009 x_{10}\end{array}$ & 0.47 & 0.0001 \\
\hline
\end{tabular}

Dependent variables: ROFA=right ovary follicular activity, LOFA=left ovary follicular activity, ROS=right ovary size, LOS=left ovary size, ROSh=right ovary shape and LOSh=left ovary shape. Independent variables: $\mathrm{X}_{1}=$ ranch, $\mathrm{X}_{2}=$ racial group, $\mathrm{X}_{3}=$ age, $\mathrm{X}_{4}=$ Body condition score, $\mathrm{X}_{5}=$ Proximity of male, $\mathrm{X}_{6}=$ nutrition-health index, $\mathrm{X}_{7}=$ thoracic index, $\mathrm{X}_{8}=$ body index, $\mathrm{X}_{9}=$ lateral body index, $\mathrm{X}_{10}=$ transverse-pelvic index.

The stimulating effect of the males' presence in the females' lots (Male effect) showed a positive impact on the onset of the ovarian activity. The fact of keeping females and males in the same lot of animals proved that the onset of the ovarian activity can be stimulated $(\mathrm{p}=0.13)$, in the bovines bred under the dual purpose system in the Huasteca Veracruzana (Table 2). In this regard, Diskin and Kenny (2014) reported that prepuberal heifers exposed to bulls advanced puberty; although the physiological mechanism is not well defined, the possibility has been proposed that the reduction in sensitivity to estradiol caused by masculine pheromones increases the secretion of the gonadotropin liberating factor and the luteinizing hormone.

Table 2. Significance of the parameters of the multiple regression equations of the categorical variables for the modeled variables ROFA, LOFA, ROS, LOS, ROSh and LOSh in bovines older than 12 months raised in the dual-purpose system in the Huasteca Veracruzana.

\begin{tabular}{l|l|l|l|l|l|l|l|l|l|l|l}
\hline \multirow{2}{*}{ Variable } & \multicolumn{10}{c}{ Categorical variables } \\
\cline { 2 - 12 } & $\mathbf{R}$ & $\mathbf{R G}$ & $\mathbf{A g}$ & $\mathbf{B C S}$ & $\mathbf{P M}$ & $\mathbf{N H I}$ & $\mathbf{T I}$ & $\mathbf{B I}$ & LBI & TPI \\
\hline ROSh & 0.84 & 0.005 & 0.02 & 0.43 & 0.0009 & 0.0005 & 0.87 & 0.71 & 0.68 & 0.002 \\
\hline ROS & 0.0002 & 0.9149 & 0.33 & 0.07 & 0.48 & 0.11 & 0.35 & 0.45 & 0.62 & 0.42 \\
\hline ROFA & 0.68 & 0.95 & 0.01 & 0.75 & 0.13 & 0.22 & 0.001 & 0.0002 & 0.0009 & 0.36 \\
\hline LOSh & 0.95 & 0.07 & 0.85 & 0.05 & 0.002 & 0.02 & 0.28 & 0.34 & 0.36 & 0.23 \\
\hline LOS & 0.0001 & 0.38 & 0.41 & 0.10 & 0.15 & 0.07 & 0.05 & 0.09 & 0.12 & 0.46 \\
\hline LOFA & 0.68 & 0.95 & 0.01 & 0.75 & 0.13 & 0.22 & 0.001 & 0.0002 & 0.0009 & 0.36 \\
\hline
\end{tabular}

Modeled variables: ROFA=right ovary follicular activity, LOFA=left ovary follicular activity, ROS=right ovary size, LOS=left ovary size, ROSh=right ovary shape and LOSh=left ovary shape. Categorical variables: $\mathrm{R}=$ ranch, $\mathrm{RG}=$ racial group, $\mathrm{Ag}=$ age, $\mathrm{BCS}=$ Body condition score, $\mathrm{PM}=$ Proximity of male, $\mathrm{NHI}=$ nutritionhealth index, $\mathrm{TI}=$ thoracic index, $\mathrm{BI}=$ body index, $\mathrm{LBI}=$ lateral body index, $\mathrm{TPI}=$ transverse-pelvic index.

Choudhary et al. (2020) researched the biostimulating effect of the presence of the male in Sahiwal heifers of 14 months of age in confining conditions, and they found that biostimulated females began ovarian activity five months before those that were not 
biostimulated $(\mathrm{p}<0.05)$. In addition, they reported that the contact with males affected positively the serum concentrations of progesterone $\left(2.0 \mathrm{ng} / \mathrm{mL}^{-1}\right)$, in comparison to the control group with concentrations lower than $1 \mathrm{ng} / \mathrm{mL}(\mathrm{p}<0.05)$. Rekwot et al. (2000) showed that biostimulation (exposure to vasectomized males) reduced the age at puberty in Bunaji and Friesian $\times$ Bunaji heifers managed in grazing; they found that biostimulated heifers began puberty at an age of $23.10 \pm 0.4$ months, while the females that did not receive biostimulation began puberty at $26.40 \pm 0.4$ months of age $(p<.05)$. Fiol et al. (2010) found a higher proportion of cyclic animals at the end of the exposure period in Aberdeen Angus $\times$ Hereford crossed heifers (Age 11 months, under grazing conditions), exposed to androgenized steers, in comparison to females that were kept isolated from the males; they also determined that the age at puberty of females exposed to males was lower compared to those not exposed (428 vs 441 days) $(p=0.06)$. Therefore, biostimulation would be efficient to reduce the age at puberty in heifers of different genetic characteristics and under different management conditions.

Oliveira et al. (2009) showed a reduction in age at puberty, age at first season of mounting, age at pregnancy, and higher rate of pregnancy in Nelore heifers supplemented and not supplemented exposed to the bull at prepuberal phase. Thus, the degree of development, the nutritional status, and the rates of gain have a direct relationship with the age at puberty in meat heifers (Diskin and Kenny, 2014). The significance value of the categorical variable racial group ( $R G)$ was $p=0.95$ (Table 2), which indicates that in this study the genetic characteristics did not have an impact on the onset of the ovarian activity. These results are set against what was reported by Rekwot et al. (2000), who found that the F1 Friesian $\times$ Bunaji heifers bred in grazing began puberty at 23.6 months of age, while the lot of pure breed Bunaji females began puberty at an age of 26.1 months ( $p<0.05)$.

The modelled variables ROSh and LOSh were influenced significantly by the categorical variables, nutrition-health index (NHI) $(p=0.0005)$, proximity to the male $(P M)(p=0.0009)$, transverse-pelvic index (TPI) $(p=0.002), G R(p=0.005)$ and $A(p=0.02)$. The rest of the categorical variables showed low relevance on the modelled variables. This could indicate that the shape of the ovaries depends on the nutritional and health management that they receive since their breeding stage, until the beginning of their reproductive stage, and that this is all directly related with its anatomical development and physiological maturity. The modelled variable LOS was affected significantly by the categorical variable TI $(\mathrm{p}=0.05)$, followed by the effect of the categorical variable NHI $(p=0.07)$ and with lower effect the categorical variable BI $(p=0.09)$; however, it was found that the size of the ovary was not significantly affected by the PM variable $(p=0.15)$. These results are contrary to those reported by Choudhary et al. (2020) who mention that biostimulation affects the number of small follicles present in Sahiwal heifers of 14 months of age under confinement conditions. These authors found that the groups of females not exposed to males produced a lower number of small follicles in comparison to the groups of biostimulated females with the presence of the male $(\mathrm{p}<0.05)$. 
The cluster analysis formed two main groups (I and II). Group II showed the best behavior of the modelled variables while group I presented a low behavior for these same variables (Figure 1). Within group II, the best behavior corresponded to livestock production with animals of the racial group Bos taurus $\times$ Bos indicus, 14 months of age, body condition of 2.75 , and the females with ovarian activity were concentrated in this group. Meanwhile, in group I livestock of low behavior was for individuals with amorphous ovaries, of smaller size and absence of ovarian activity (Figure 1).

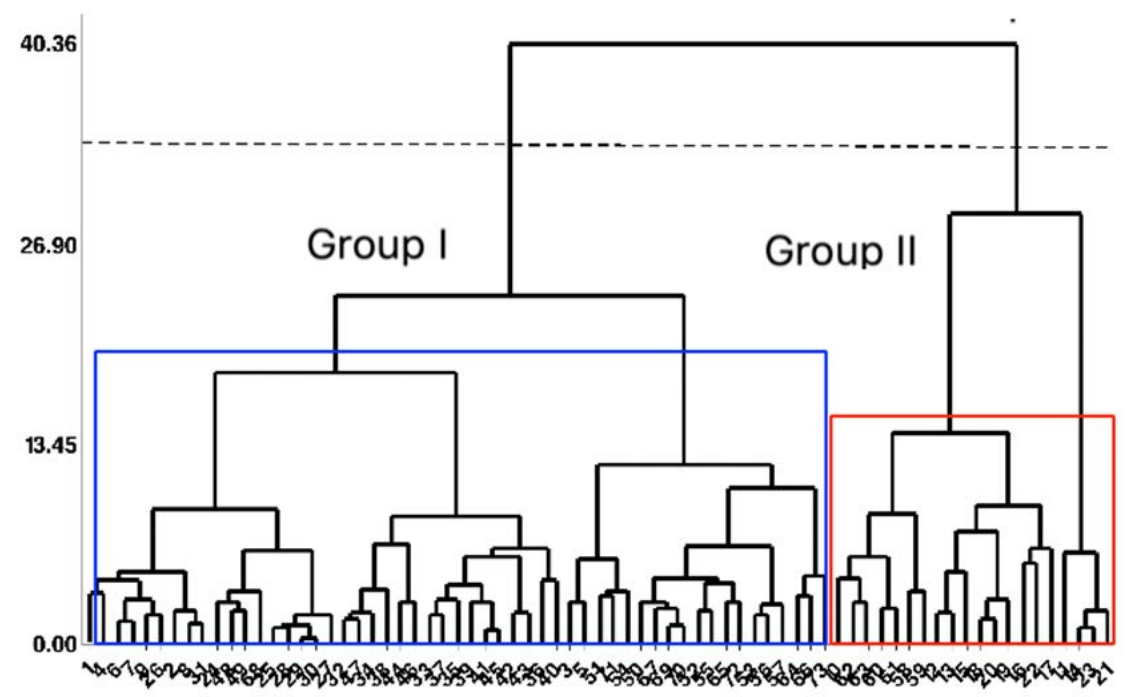

Figure 1. Dendrogram of dependent variables (shape, size and follicular activity of right and left ovary) and categorical variables (ranch, racial group, age, body condition score, proximity of male, nutrition-health index, thoracic index, body index, lateral body index, transverse-pelvic index) for the dual-purpose bovine system in the Huasteca Veracruzana.

\section{CONCLUSIONS}

The heifers reared in the dual-purpose system in the Huasteca Veracruzana could begin the ovarian activity at a younger age when their anatomical development, expressed in zoometric indexes, are of higher value and when the chronological age is over 14 months. The biometric measurements of heifers are a useful tool as parameter for the selection of replacements when the intent is to improve the sexual precocity of the herd. The husbandry practices designed to reduce the age at puberty should be directed at improving the quality of the diet. There is a need to research alternatives and practices of viable nutritional management (ecologically and economically) for replacement females in the DPCPS, and with this to guarantee an anatomical development in agreement with their genetic potential. The genetic improvement programs designed to reduce the age of puberty could lack effectiveness if the breeds or racial groups evaluated in this research are used. Biostimulation (presence of the male) is a useful tool to reduce the age at which the ovarian activity of heifers begins. 


\section{REFERENCES}

Cardoso, L.C., King, A., Chapwanya, A. \& Esposito, G. (2021). Ante-Natal and Post-Natal Influences on Neonatal Immunity, Growth and Puberty of Calves. Animals, 11(5): p.1212. doi: https://doi.org/10.3390/ani11051212

Choudhary, S., Kamboj, M., Raheja, N., Kumar, N., Saini, M. \& Lathwal, S. (2020). Influence of bull biostimulation on age at puberty and reproductive performance of Sahiwal heifers. Indian Journal of Animal Sciences, 90(1), pp.28-34.

Contreras, G., Chirinos, Z., Zambrano, S., Molero, E. \& Paéz, A. (2011). Caracterización morfológica e índices zoométricos de vacas Criollo Limonero de Venezuela. Revista de la Facultad de Agronomía de la Universidad del Zulia, 28(1), pp.91-103.

Diskin, M.G. \& Kenny, D.A. (2014). Optimising reproductive performance of beef cows and replacements heifers. Animals, 8(1), pp.1-13. Doi:10.1017/S175173111400086X

Dubuc, M.W. (1991). Zoometría. Zootecnia General. (3ra ed.). Caracas, Venezuela: Ediciones Dumar. pp. $281-289$.

Edmonson, A.J., Lean, I.J., Weaver, L.D., Farver, T. \& Webster, G.A. (1989). Body condition score chart for Holstein cows. Journal of Dairy Science, 72(1),pp. 68-78.

Estill, C.T. (2014). Initiation of Puberty in Heifers. En: R.M. Hopper (Ed.). Bovine Reproduction: John and Sond. pp. 195-202.

Fernandes, H. J., Tedeschi, L. O., Paulino, M. F. \& Paiva L. M. (2010). Determination of carcass and body fat compositions of grazing crossbred bulls using body measurements. Journal of Animal Science, 88(4), 1442-1453. Doi: 10.2527/jas.20091919

Fiol, C., Quintansb, G. y Ungerfeldc, R. (2010). Response to biostimulation in peri-puberal beef heifers: influence of male-female proximity and heifer's initial body weight. Theriogenology, 74(4), 569-575. Doi:10.1016/j.theriogenology.2010.03.015

Grajales, H., Hernández, A. \& Prieto, E. (2006). Age and weight at puberty and their relation with reproductive efficiency of cattle breeds in the Colombian tropics. Livestock Research for Rural Development, 18(10). http://www.lrrd.org/lrrd18/10/ graj18139.htm

Helsin, J., Kenny, D.A., Kelly, A.K. \& McGee, M. (2020). Age al puberty and pregnancy rate in beef heifer genotypes with contrasting nutritional intake from 8 to 13 months of age. Animal Reproduction Science, 212. Doi: https://doi.org/10.1016/j. anireprosci.2019.106221

Instituto Nacional de Estadística, Geografía, e Informática (INEGI). 2010. Perspectiva Estadística. Veracruz de Ignacio de la Llave. Diciembre de 2010. http://cuentame.inegi.org.mx/monografias/informacion/ver/default.aspx?tema=me\&e=30 .

Kenny, D.A., Heslin, J. \& Byrne, C.J. (2018). Early onset of puberty in cattle: implications for gamete quality and embryo survival. Reproduction, Fertility and Development, 30(1), pp.101-117. Doi: 10.1071/RD17376

Oliveira, C.M.G., Oliveira, Filho B.D., Gambarini, M.L., Viu, M.A.O., Lopes, D.T. \& Sousa, A.P.F. (2009). Effects of biostimulation and nutritional supplementation on pubertal age and pregnancy rates of Nelore heifers (Bos indicus) in a tropical environment. Animal Reproduction Science, 113(1-4), pp.38-43. Doi: 10.1016/j.anireprosci.2008.08.006

Orantes, Z.M.A., Vilaboa, A.J., Ortega, J.E. \& Córdova, A.V. (2010). Comportamiento de los comercializadores de ganado bovino en la región centro del estado de Chiapas. Revista Quehacer Cientifico, 1(9), pp.51-56.

Osorio-Arce, M. \& Segura-Correa, J. (2002). Reproductive performance of dual purpose cows in Yucatán, México. Livestock Research for Rural Development, 14(3). Pp. http://lrrd.cipav.org.co/lrrd14/3/Osor143.htm

Parra-Bracamonte, G.M., Magaña, J.G., Delgado, R., Osorio, M. \& Segura, J.C. (2005). Genetic and non-genetic effects on productive and reproductive traits of cows in dual purpose herds in Southeastern Mexico. Genetics and Molecular Research, 4(3), pp.482-490.

Programa Sectorial Alimentando Veracruz (PSAV). (2019). Gaceta Oficial del Estado de Veracruz. Xalapa-Enriquez, Ver. Disponible en línea: http://www.veracruz.gob.mx/finanzas/wpcontent/uploads/sites/2/2019/11/Alimentando-veracruz.pdf.

Rekwot, P., Ogwub, D., Oyedipea, E. \& Sekonia, V. (2000). Effects of bull exposure and body growth on onset of puberty in Bunaji and Friesian X Bunaji heifers. Reproduction Nutrition Development, 40 (4), 359-367. Doi: 10.1051/rnd:2000104 
Teyer, B.R., Magaña, J.G., Santos, J. \& Aguilar, J.C. (2003). Comportamiento productivo y reproductivo de vacas de tres grupos genéticos en un hato de doble propósito en el sureste de México. Revista Cubana de Ciencia Agrícola, 37(4), pp.363-370.

Vilaboa, A.J. \& Díaz, R.P. (2009). Caracterización socioeconómica de los sistemas ganaderos en siete municipios del estado de Veracruz, México. Zootecnia Tropical, 27(4), pp.427-436. 